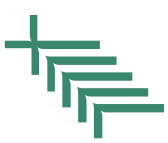

Folia

Scandinavica Posnaniensia

Folia Scandinavica

VOL.31, 2021 (p. 15-22)

DOI: 10.2478/fsp-2021-0004

\section{The present participle and gender assignment in Swedish}

Dominika Skrzypek (Adam Mickiewicz University in Poznań)

\section{Abstract}

The paper considers gender assignment of deverbal nouns, originally present participles, in Swedish. The perspective is diachronic. The corpus consists of a choice of Swedish texts from 1225-1732. The results show that nouns denoting entities ranking higher in the Animacy hierarchy show tendencies to be placed in the utrum gender (originally masculine and feminine genders) and nouns denoting mass, collective or abstract referents to be assigned neuter gender. This tendency is visible throughout the history of the Swedish language.

Keywords: present participle, gender assignment, Swedish, language change 


\section{INTRODUCTION}

The North Germanic languages have inherited the PIE gender system, with three genders, masculine, feminine and neuter. As is the case with other grammatical categories, gender is subject to change and with time can expand and develop or be reduced. The gender system relies on forms, which themselves may change or decline, new forms may also be added to the existing repertoire. In the course of their individual histories, the western branch of the North Germanic languages (Icelandic, Faroese and most variants of Norwegian) has retained the tripartite gender, while the eastern branch (Danish, Swedish and variants of bokmål based on Danish) has reduced it to two values, the original masculine and feminine genders having coalesced into one gender, utrum, in these languages. What happened in Danish and Swedish is an example of partial reduction, with the grammatical category remaining in place, but with a reduced number of values.

In the oldest attested forms of North Germanic, the gender of each noun manifested itself through case endings, agreeing forms of adjectives, possessive pronouns, anaphoric pronouns and, in time, articles (definite and indefinite). In the Middle Ages, chiefly between 1200s and $1500 \mathrm{~s}$, the languages of the eastern branch of the North Germanic underwent a number of tumultuous changes in their grammars, including loss of the case system, rise of definite and indefinite articles and a number of syntactical changes which followed, such as obligatorification of subject. The gender system, however, remained intact, with new markers, such as articles, continuing to signal the gender of the noun. Anaphorically, the discourse referents continued to be presented as han 'he', hon 'she' or det 'it'.

Between mid-1500s and late 1800s the grammatical gender in Swedish was reduced to two values, which manifested itself in the form of the definite and indefinite articles: -en became the common definite article for both masculine and feminine nouns, -et remained the definite article for the neuter nouns. Similarly, the indefinite article went from enn/en to en only for both masculine and feminine nouns. With the case system reduced (the sole survivor is the s-genitive, a clitic, used with all nouns irrespective of gender), the only scope for tripartite gender were the anaphoric pronouns, however, this period saw the rise of a new pronoun, den, which could be used anaphorically to refer back to nouns of either masculine or feminine gender, as long as they denoted inanimate (or even non-human) referents. Den became predominant in official prose as early as in the late 1600s (Davidson 1990). The resulting system is partly reliant of morphology (agreement) and partly on semantics (anaphoric pronouns).

The aim of the present paper is to consider the gender system of Swedish in a diachronic perspective, paying attention to the deverbal nouns, originally present participles and the principles of gender assignment. The diachronic dimension will allow us clearer insight into the semantic foundations of gender assignment.

The paper is organized as follows: in section 2 we discuss the gender in Modern Swedish (MSw) in more detail, with relevant examples. In section 3 we present the problem at hand, i.e., the lexicalized present participles which are nouns. Section 4 is a presentation of the current study. Section 5 includes a summarizing discussion and outlook towards further studies.

\section{GENDER IN MODERN SWEDISH}

A common understanding of what the grammatical gender is may be found in Charles Hockett's definition "Genders are classes of nouns reflected in the behaviour of associated words" (Hockett 1958:231). This definition is based purely on formal criteria and does not 
include a semantic component. Grammatical gender is similarly defined in Svenska Akademiens Grammatik (SAG), which states:

[g]enus, lexikal grammatisk egenskap hos substantiv, vilken avgör formen på bestämdhetssuffixet i singularis (båt-en, hus-et) och påverkar bl.a. valet av kongruensböjd form för pronomen och adjektiv som attribut och predikativ. Genus är antingen utrum eller neutrum. (SAG 1999: vol. 1, 176)

Thus, the grammatical gender in MSw is seen as an inherent property of each noun, which regulates the form of the definite and indefinite articles as well as attribute and predicative agreement. Teleman (1987:107ff) claims that gender in Swedish in the majority of cases has no foundation in the meaning of the noun and is fully arbitrary.

(1) Det nya huset är stort.

DEM.N new house.DEF.N is large.N

'The new house is large.'

(2) Den nya båten är liten.

DEM.U new boat.DEF.U is small.U

'The new boat is small.'

This position is found in other works on gender assignment in MSw (among others: Josefsson 2002, 2005, 2006 and 2010 and Källström 1995 and 1996). However, MSw exhibits also semantic gender, which is manifested in the choice of anaphoric pronoun. For nouns which denote inanimate beings and animates located low in the Animacy Hierarchy (Silverstein 1976), the anaphoric pronoun is chosen according to the grammatical gender, either den for utrum or det for neutrum. For nouns denoting animates located high in the Animacy Hierarchy (typically humans), the choice of the anaphoric pronoun is dependent on the semantic properties of the referent, i.e., the biological sex, and the forms available are han 'he' and hon 'she'.

(3) Var är läkaren? - Han är där. / Hon är där.

'Where is the doctor? - He is there. / She is there.'

There is no straightforward correspondence between the grammatical and biological gender, it should however be noted that there are very few neuter nouns which denote humans, or indeed, animates. In this group we find among others barn 'child', vittne 'witness', statsråd 'minister' and lejon 'lion', but they are rare and notoriously difficult when appearing in anaphoric chains. The grammatically correct det 'it' is usually avoided in favour of personal pronouns referring to humans (see above), including hen ' $\mathrm{s} / \mathrm{he}$ ', if the sex of the referent is not known.

(4) Vad säger vittnet? Att han/hon/hen inte hörde skottet.

What says witness.DEF.N That he/she/s/he not heard shot.DET.N

The position presented in Hockett 1958, Teleman 1987 and SAG is formalistic and traditional. It finds support in the modern data - it is usually not possible to predict the gender of the noun based on its denotation alone - but it does not consider the diachrony of the gender system and therefore misses, to some extent, the semantic aspect of gender assignment, which is an inherent part of any gender system.

At the same time, gender always has a semantic core: there are no gender systems in which the genders are purely formal categories. (Corbett 1991:307) 
The semantic foundation of gender assignment is reflected in the ability of the language users to assign gender correctly and consistently, also when dealing new (e.g. borrowed) lexical material. The idea of semantic foundations of gender is most clearly stated in Corbett's seminal work on the typology of gender systems.

First, native speakers typically make few or no mistakes in the use of gender; if the gender of every noun were remembered individually, we would expect more errors. Second, words borrowed from other languages acquire a gender, which shows that there is a mechanism for assigning and not just remembering gender. And third, when presented with invented words, speakers give them a gender and they do so with a high degree of consistency. Thus native speakers have the ability to 'work out' the gender of a noun. (Corbett 1991:7)

Similarly, Audring 2008 states that there are no gender systems which are entirely formally organized, but that semantic rules always play some part in gender assignment.

While logically there are three types of assignment systems, only two of them are found. The two types are languages whose gender system is entirely semantically organized and languages with a mixed semantic and formal rule systems. The third type, a purely formally organized gender system, is not attested. This suggests that formal and semantic rules have a different status in gender systems and thus in the speakers' minds. (Audring 2008:113f)

Gender assignment in the North Germanic languages has not been studied systematically until very recently. The question is taken up in Trosterud 2001 and 2006 (on gender in Norwegian), in Kilarski and Krynicki 2005 (on gender assignement of English loanwords in Danish, Norwegian and Swedish) and in Akerblom 2012, who tests the idea of semantic foundations of gender in MSw. His analysis suggests that gender assignment in MSw seems to be founded, at least partly, on the animacy status of the noun (and thus is to an extent semantically motivated).

Det tycks först och främst finnas en tydlig koppling mellan animacitet och ett substantivs genus och därmed mellan ett substantivs betydelse och genus. Därtill görs en åtskillnad mellan räknebara substantiv och icke-räknebara, vilket även det återkopplar till ordets betydelse. Undersökningen har också visat att inanimata neutrer (vilka är få) inte gärna ger upphov till neutral kongruens i predikativet, det enda neutrala animata substantivet som tycktes helt bekväm med sitt genus var barn men även detta kan förklaras med en underliggande semantik. (Åkerblom 2012:97)

The most recent study of gender assignment is Van Epps et.al. (2021). The authors have looked at Old Norse, Norwegian nynorsk, Old and New Swedish, Jamtlandic and Elfdalian. Apart from purely formal criteria, they highlight the role of semantic ones as well, mainly animacy. This study is one of the few that consider gender assignement in North Germanic from a diachronic perspective (cf. Enger 2004a and 2004b and Davidson 1990).

\section{THE LEXICALIZED PRESENT PARTICIPLE}

The present participle in Germanic (GMC) is based on an IE suffix *-o-nt, added to the present stem (Harbert 2007:341), in Modern Swedish (MSw) -ande/-ende. The present participle has active meaning, in the sense that its predication base corresponds to the subject of the verb from which it is derived, e.g. en leende hovmästare 'a smiling chef' is equivalent to en hovmästare som ler 'a chef who is smiling' (SAG vol. 2:610). In MSw it is associated with a number of constructions, giving it a verbal (5), adverbial (6), adjectival (7) or nominal (8) character. 
(5) Jag gick efter honom en stund och såg honom än tappande sin näsduk, än kastande en sten ut över fälten, än stoppande ner sina glasögon i fickan.

'I went after him for a while and saw him now dropping his handkerchief, now throwing a stone over the fields, now stuffing his glasses in his pocket.'

(6) Barnen kom springande fram ur buskaget.

'The children came running out of the shrubbery.'

(7) Johan var övertygande.

'Johan was convincing.'

(8) Ingen hade respekterat de närmast sörjandes önskemål.

'Nobody had respected the wishes of the closest mourners (lit. the closest grieving).'

(all examples quoted after SAG 2:610-623)

It has been claimed in earlier research that the present participle in Old Swedish (OSw, 1225-1550) has more nominal than verbal features and that it gradually acquires more verbal character during that period, most likely under the influence of Latin (Ahlberg 1942). This observation tallies well with the history of the English gerund (Miller 2002, Fonteyn 2019). In the oldest extant Swedish texts, the legal prose, there seem to be rather few instances of verbal uses of the present participle. These texts are relatively free from foreign influence, although it cannot be categorically dismissed, not least because the literate in the Swedish society were most likely fluent in Latin as well. However, the use of the present participle in these texts (as well as in the Runic inscriptions) is the closest we can come to the original scope of use and categorial nature of the form. The data suggest a nominal character of the participle. In OSw a number of legal terms for participants of legal proceedings are in fact present participles, e.g. kärande, saksökiande, malsäghande 'plaintiff', svarande, väriande 'defendant', äghande 'owner', iorthäghande 'landowner', quäräghande 'mill-owner', scoghäghande 'forest-owner' (Ahlberg 1942:16). Some of these terms remain part of the legal jargon in MSw. Very ancient, and common to all GMC languages, are nouns bonde 'yeoman', compare with EN 'husband', frände 'friend' and fiende 'fiend, foe'.

When used nominally, the present participle can be inflected for number and definiteness. Gender assignment seems to be dependent on whether it is the agent or the event itself (as expressed by the verb) that is in focus. The agent is assigned utrum gender and the process/event neutrum. Consider the two examples, in which two nouns are used, both derived from the VP söka asyl 'apply for the asylum'.

(9) Det kan hända mycket medan en asylsökande väntar på besked.

'Much can happen while an asylum seeker is waiting for the decision.'

(10) Jämfört med år 2000 har asylsökandet fördubblats.

'Compared with year 2000 asylum application has doubled.'

(spraakbanken, 07.10.2021)

In the following section we will consider the gender assignment in a diachronic perspective.

\section{THE DIACHRONIC STUDY}

The data for the present study was gleaned from the diachronic corpus accessible via the Spraakbanken home page. It includes texts from the Fornsvenska textbanken (see https://project2.sol.lu.se/fornsvenska/), spanning years 1225-1732. The Old Swedish material is more than twice as large as the New Swedish, but it spans a much longer period, too. 


\begin{tabular}{|c|c|c|c|}
\hline \multirow{2}{*}{} & \multicolumn{2}{|c|}{$\begin{array}{c}\text { Old Swedish } \\
(1225-1526)\end{array}$} & $\begin{array}{c}\text { New Swedish } \\
(1526-1732)\end{array}$ \\
\hline periods & Classical (1225-1350) & Younger (1350-1526) & \\
\hline tokens & 1022797 & 1644148 & 1006044 \\
\hline
\end{tabular}

(Fig. 1) Spraakbanken's diachronic corpus

Spraakbanken allows for a simple search of the corpora, in which individual forms can be searched for and some forms can be excluded. For the purpose of the present study we have defined the search strings as words ending in (=ord slutar med) anden/enden or andet/endet, which returns the definite forms of the present participle, at the same time excluding (=ord är inte) frequently appearing tokens such as landet 'the country', utlandet 'abroad' or anden 'spirit.DEF'. However, the results had to be culled manually to excerpt just the present participle forms.

A further search was made to excerpt indefinite forms, i.e., en/ett plus a form ending in andelende. However, this search returned very few results, as the majority of the participles were used not as nouns, but as adjectives, as in the following example.

(11) Midt uti war uprest en brinnande Thron 'In the middle a burning throne was raised.'

(Dalin 1732)

An overview of the results is given in Table 2 below.

\begin{tabular}{|c|c|c|}
\hline Tokens & $\begin{array}{c}\text { Old Swedish } \\
(1225-1550)\end{array}$ & $\begin{array}{c}\text { New Swedish } \\
(1550-1750)\end{array}$ \\
\hline -anden/-enden & 224 & 3 \\
\hline -andet/-endet & 0 & 33 \\
\hline
\end{tabular}

(Fig. 2) Nominal present participles in Old and New Swedish

As can be seen, the present participle used nominally (and in definite form) is sparsely represented in the Old Swedish material, even more so in the New Swedish corpus. The discrepancy between the two periods is mainly due to there being more legal texts in the Old Swedish corpus and only a few in the New Swedish. A closer look at the data reveals that the majority of all nominal present participles in Old Swedish are in fact legal terms denoting the participants of legal actions, e.g. malseghanden 'plaitiff.DEF' makes for about half of all participles (114 instances). Interestingly, there are no instances of the nominal present participle of neuter gender in the Old Swedish material.

The Old Swedish material consists of not just the masculine (most likely) participles, but also of concrete, individuative nominals only. The New Swedish material is exactly the opposite: there are almost only nominals which denote the process, not the agent, such as läppiandet 'sipping.DEF', bräkandet 'bleating.DEF', åhörandet 'hearing.DEF', supandet 'boozing.DEF', susandet 'swooshing.DEF' and sprättandet 'cracking.DEF'.

(12) jag kan undra på detta fäktandet och fikandet öfwer ingen ting (Dalin 1732) 'I can wonder at this scurrying and hurrying over no thing.'

The surprising asymmetry in the data from Old and New Swedish is partly dependent on the discrepant genres included in each corpus (of necessity, as the oldest extant Swedish texts 
are almost exclusively legal prose). Were we to disregard the participles which are legal terms, we would find just one nominal participle, tidande 'news' (cf. English tiding and Modern Swedish tidning 'newespaper'). However, there may be a further reason for the difference between the Old and New Swedish material, namely the development of the present participle itself, from a more nominal towards a more verbal category. It should be noted that almost all present participles used as nouns in New Swedish appear in constructions where a subordinate clause would be preferred in Modern Swedish.

(13) Der kan han förlusta sig med åskådandet af Riken, Folk och Städer (...).

'There he can lose himself with the viewing of kingdoms, peoples and cities (...).'

(spraakbanken: Dalin 1732)

These participles all denote abstract entities, processes or events rather than individualized discourse referents and as such are located very low on the Animacy Hierarchy.

\section{DISCUSSION}

The present study into gender assignment with nominally used present participles in the history of the Swedish language has revealed the pervasiveness of Animacy hierarchy, also in a diachronic perspective.

(14) Animacy hierarchy human $($ male $/$ female $)>$ animate $>$ inanimate $>$ mass $/$ abstract

Even if gender assignment is about tendencies rather than absolute rules, it is clear that the more animate, individualized entities tend to be placed in the utrum (originally masculine or feminine) gender and the abstract or collective nouns tend to be presented as neutra. This is especially clear in the case of polysemous nouns, where the more animate denotation is given the gender utrum, and the more inanimate one neutrum, e.g. en studerande 'a student' vs. (ett) studerande 'studying'

This tendency is present in all Mainland Scandinavian languages, in both standard and regional varieties (Van Epps 2021). Even though gender assignment has been more formally based in earlier variants of Scandinavian, its semantic underpinnings are of old date. One could say that while the utrum gender is not exclusively connected with animacy, there is a tendency for the nouns of the neuter gender to denote inanimate rather than animate reference, as well as uncountable and collective referents. This tendency is also exploited in the southern and western dialects of Danish, in which the gender reduction seems to be more advanced than in Standard Danish or Swedish.

SEMANTISK GENUS el. FRIT GENUS er en betydningsegenskab ved bøjningskategorien genus, ikke ved substantivstammer. I de tilfælde hvor man kan finde en tydelig sammenhæng mellem semantik og genus, er utrum det genus der betegner et individ eller en genstand og har betydningen 'individueret'. Neutrum betyder 'ikke-individueret' og kan bruges både til at betegne stof eller masse (det utællelige) eller neksuale forhold der er utællelige. (Hansen \& Heltoft 2011:455f)

The diachrony of the present participles turned nouns in Swedish shows that the role of the animacy in gender assignment has a much longer history than the gender reduction in the $1600 \mathrm{~s}$. The principles which seem to guide gender assignment today seem to have been at play from the earliest documented use of Swedish, so that the neuter gender was associated with the collective or abstract nouns, while individuative nouns were assigned masculine gender. The results tell a lot about the nature of the present participle as well, which develops 
from more nominal to more verbal uses. The former render new nouns, with animate, individuative denotation, such as ordförande 'chairman', while the latter result on nouns denoting actions, events of processes, which are placed in the neuter gender.

\title{
SOURCES
}

Spraakbanken, diachronic corpus of Swedish available at spraakbanken.gu.se.

\section{REFERENCES}

Ahlberg, M. (1942). Presensparticipet i fornsvenskan: en syntaktisk studie. Diss. Stockholm: Högsk.. Lund.

Audring, J. (2008). Gender assignment and gender agreement: Evidence from pronominal gender languages. Morphology 18:93-116.

Åkerblom, S. (2012). Genus - tilldelat eller inherent? Ms available at: https://www.academia.edu/9278603/_Genus_tilldelat_eller_inherent

Corbett, G. (1991). Gender. Cambridge: Cambridge University Press.

Davidson, H. (1990). Han hon den: Genusutvecklingen i svenskan under nysvensk tid. Lund: Lund University Press.

Enger, H.-O. (2004a). On the relation between gender and declension: A diachronic perspective from Norwegian. Studies in Language 28. 51-82.

Enger, H.-O. (2004b). Tre endringer i det skandinaviske genussystemet i lys av grammatikaliseringsteori. Arkiv för Nordisk Filologi 119. 125-146.

Fonteyn, L. (2019). Categoriality in language change: the case of the English gerund. New York, NY: Oxford University Press.

Hansen, E. \& Heltoft, L. (2011). Grammatik over det danske sprog. Copenhagen: Det danske Sprog- og Litteraturselskab.

Harbert, W. (2007). The Germanic languages. Cambridge: Cambridge University Press.

Hockett, Ch. (1958). A Course in Modern Linguistics. New York: Macmillan.

Josefsson, G. (2002). Tjänis, knäppis och brallis; om suffixet -is i modern svenska. Ms. Institutionen för nordiska språk, Lunds universitet.

Josefsson, G. (2005). Ord. Lund: Studentlitteratur.

Josefsson, G. (2006). Semantic and grammatical genders in Swedish - independent but interacting dimensions. Lingua 116:1346-1368.

Josefsson, G. (2010). "Disagreeing" pronominal reference in Swedish and the interplay between formal and semantic gender. Lingua 120/9:2095-2120.

Källström, R. (1995). Om svenskans genussystem. Göteborg: Göteborgs universitet.

Källström, R. (1996). On gender assignment in Swedish. The Nordic languages and modern linguistics. Proceedings of the Ninth International Conference of Nordic and General Linguistics, University of Oslo, January 10-11, 1995, ed. by Kjartan G. Ottósson, Ruth V. Fjeld, \& Arne Torp, 151-167. Oslo: Novus Forlag.

Kilarski, M. \& Krynicki, G. (2005). Non arbitrary, not regular: The magic of gender assignment. (12.2.2012). www.staff.amu.edu.pl/ kilarski/research/download/leuven.pdf

Miller, D.G. (2002). Nonfinite structures in theory and change. Oxford: Oxford University Press.

$\mathrm{SAG}=$ Svenska Akademiens Grammatik 1-4. 1999. Stockholm: Nordstedts.

Silverstein, M. (1976). Hierarchy of features and ergativity. In: Dixon RMW (ed.) Grammatical categories in Australian languages. Canberra: Australian inst. of aboriginal studies, pp. 112-171.

Teleman, U. (1987). Grammatik på villovägar. Stockholm: Almqvist \& Wiksell.

Trosterud, T. (2001). Genustilordning i norsk er regelstyrt. Norsk Lingvistisk tidsskrift 19:29-58.

Trosterud, T. (2006). Gender assignment in Old Norse. Lingua 116. 1441- 1463.

Van Epps, B., Carling, G., \& Sapir, Y. (2021). Gender Assignment in Six North Scandinavian Languages: Patterns of Variation and Change. Journal of Germanic Linguistics, 33(3), 264-315. doi:10.1017/S1470542720000173

\section{Dominika Skrzypek}

\author{
Adam Mickiewicz University in Poznań \\ Chair of Scandinavian Studies \\ Al. Niepodległości 4 \\ 61-874 Poznań \\ Poland \\ dosk@amu.edu.pl
}

